\title{
Influence of Flipped Classroom and Social Engagement on Vocational Students' Speaking Performance
}

\author{
Zelhendri Zen \\ Education Faculty \\ State University of Padang, Indonesia \\ zelhendrizenzen@yahoo.mail
}

\author{
Reflianto \\ Postgraduate Students, \\ State University of Malang, Indonesia \\ refliantomuslim@gmail.com
}

\begin{abstract}
The aims of the research were to analyze the influence of the flipped classroom model and students social engagement in the vocational class. The method of study was experimental-quantitative research with survey methods. The subject of the research was eleventh-grade students of State Vocational School Number 2 Padang as many as 60 people. The data of Students' social engagement were collected by using questionnaires with a 5-point Likert scale and speaking performance data were collected by using Oral English Competency Test. Analysis of data used multiple linear regression tests. The finding of the research reported that the implementation of a flipped classroom model to strengthen Students' social engagement in the line of socialization ability; personal communication ability and self-control to cooperate with others have a significant relationship with students' speaking performance. English teachers can utilize the flipped classroom model to a foreign language learner class to improve students' speaking performance by strengthening social engagement.
\end{abstract}

Keywords: flipped classroom, students' social engagement, speaking performance

\section{INTRODUCTION}

In recent years the model flipped classroom widely adopted to support pedagogy. Flipped Classroom model application is made to give the attractiveness of learning in students, increasing students' success and improving the ability of students' affective. Talbert, the use of video media on students' interest and their learning outcomes [1], while Wrigh, examined the influence of the flipped classroom model by using printed media and written records are prepared to make students more active and participative in class. In all cases, the dominant class time devoted to individual work and group directed to solve problems and find out appropriately solutions [2].

Johnson, et. al., that flipped classroom is a learning model that was developed in the last one or two years. The flipped classroom is a change of teaching from teacher center to student center wherein the classroom students learning more discussion by providing meaningful learning opportunities for all students to discuss the material that they have learned at home before class begins [3]. The task of material given can be learned at home by using educational technology media such as online video and used to 'deliver content' outside of the classroom.

In the context of flipped Classroom model, the content delivery' can take many forms such as video lessons, handouts, and text prepared by the teacher or a third party to be used to convey the content, meaning of subject by using flipped classroom model so this model not only use collaborative media online or digital media, but also can use the printed media such as reading text [4]. Meanwhile, Devices Dean and Bali adds that the learning objectives of the flipped classroom are more to strengthening the discussions class and interactive communication class to solve the given problems related to the material that has been studied previously by students at home or outside the classroom
Today, the implementation of the flipped classroom is strongly related to the strengthening of social engagement and student academic performance has not been done. The many International scientific studies recommend that this topic needs further research about strengthening social engagement and its relationship with students' speaking performance especially in teaching English as a foreign language to improve students' communication through strengthening their engagement social.

Lowell, Utah, Verleger, \& Beach, in their metaanalysis stated that of eleventh related study about flipped classroom model, in fact there has not been a single study of affective factors for EFL learners to explore the effect of flipped classroom on students' communication skills, because so far the related research of flipped classroom is more associated with motivation, self-efficacy and learning outcomes, whereas the reinforcement of students' social engagement is important to the smooth discussion and interactive communication among students in the classroom, particularly for teaching speaking in the class of English Language Learner. [5] state that whatever the discussion active or not in class, nothing the reinforcement of social engagement was escaped in following the interactive teaching-learning process in the classroom.

In the UK, the flipped classroom model then becomes the pivotal study in future research. The study is more focused to the effects of flipped classroom models on positive change a student's academic performance by using flipped classroom through the continuity research of evaluating the significant effect of this model on the role of students' social involvement and its impact on their learning outcomes in the classroom. Mehring, In their case study reported that the model flipped classroom can improve students' academic performance that can be seen from formative and summative assessment. 
In English Language Learning, this model of flipped classroom have been applied by English teachers widely to build the students' self-learning regulation in the class, improve students' cooperation skills and interpersonal communication skills in discussions and interactive communication by using speaking English, it is not only in the classroom, but also outside of the classroom [6].

Today, the English teachers' task is how they can use the time more effectively to study so that students can master a foreign language well in accordance with his/her expected competencies. The model of flapped classroom provides a good chances for English teacher to utilize a lot of their time to motivated the their students in order want to learn English is more active and participative both outside and inside of the first, before the truly learning process of interactive discussion and social communication can be held in the class well [7]. To strengthen the students' social engagement in order to improve students' English-speaking performance, this study tried to examine the eleventh-grade students of SMK 2 Padang.

\section{METHOD}

Method of study used experimental quantitative approach with survey design. Creswell stated that experimental quantitative study is to test the hypothesized among variables [8]. The hypothesis of this study will be verifiable. It describes that the hypothesis has strong correlation between variables. This research used two variables are social engagement and speaking performance.

Social engagement covered three sub variables, they are socialization, personal communication and Self Control in cooperation with other. All eleventh-grade students of Senior Secondary High School of SMK 2 Padang, Indonesia, become population of this research. Sample was taken as many as 60 people. Students' social engagement data were collected by using questionnaires with 5-point Likert scale and speaking performance data were collected by using Oral English Competence Test.

Questionnaires from was used to collect the data in the field. For the data of social engagement was measured by using Likert scale with 5-point. Measuring the students' speaking performance was obtained by oral test. All questioners should be valid and reliable firstly before distributing to the respondent of research. According to Creswell the validity of the test showed the extent to which a measuring device used to measure its validity and reliability [8]. The measurement of it can be done by using product moment, the item can be considered as a valid question if it is greater than 0:30. While reliability is if all question asked of respondents trusted based on Cronbach alpha test. The inference analysis used linear multiple regression to know the relationship of social engagement and students' speaking performance.

\section{RESULTS}

The finding of the implementation of the flipped classroom model to eleventh-grade students of SMK 2 Padang has obtained the strengthening of students' social engagement for socialization ability, communication ability, and self-control as follows (Table 1). From Table 1 above showed that the category of socialization ability elements to the eleventh-grade students of SMK Negeri 2 Padang totally in the level of high with a score of 37.0. For the detail to each sub variable of socialization ability elements are in the first sub variable of the cooperative was 3.50. It consisted of in the high category as much as 25 people or $(41.7 \%)$, in the fair category 32 people or $(53.3 \%)$ and the low category 3 people or $(5.0 \%)$.

Second, the sub variable of friendly was 3.70 in the level of high. It consisted of in the high category as much as 30 people or $(50.0 \%)$, in the fair category 21 people or $(35.0 \%)$ and the low category 9 people or $(15.0 \%)$. For third sub variable of Tolerable was 3.80 in the high level which consisted of high category as much as 39 people or $(65.0 \%)$, in the fair category 7 people or $(16.7 \%)$ and the low category 11 people or $(18.3 \%)$. Finally, adaptive was 3.70 in the high level which consisted of high category as much as 38 people or $(63.3 \%)$, in the fair category 9 people or $(15.0 \%)$ and the low category 13 people or $(21.7 \%)$. For the variable of personal communication ability, the result of the analysis can be seen in the Table 2 .

Table 1

English Language Learners' Socialization Ability in Flipped Classroom Model

\begin{tabular}{|l|c|c|c|c|c|}
\hline \multirow{2}{*}{$\begin{array}{c}\text { Elements of Socialization } \\
\text { Ability }\end{array}$} & \multicolumn{3}{|c|}{ Category } & \multirow{2}{*}{ Mean } & \multirow{2}{*}{ Level } \\
\cline { 2 - 6 } & $\begin{array}{c}\text { Low } \\
(\mathbf{1 . 0 0 - 2 . 3 3 )}\end{array}$ & $\begin{array}{c}\text { Fair } \\
(\mathbf{2 . 3 4 - 3 . 6 6 )}\end{array}$ & $\mathbf{( 3 . 6 7 - 5 . 0 )}$ & & Fair \\
\hline Cooperative & $3(5.0 \%)$ & $32(53.3 \%)$ & $25(41.7 \%)$ & 3.50 & High \\
\hline Friendly & $9(15.0 \%)$ & $21(35.0 \%)$ & $30(50.0 \%)$ & 3.70 & High \\
\hline Tolerable & $11(18.3 \%)$ & $7(16.7 \%)$ & $3965.0 \%)$ & 3.80 & High \\
\hline Adaptive & $1321.7 \%)$ & $9(15.0 \%)$ & $3863.3 \%)$ & 3.70 & High \\
\hline \multicolumn{7}{|c|}{ Average } \\
\hline
\end{tabular}

Table 2

English Language Learners' Communication Ability in flipped Classroom Mode

\begin{tabular}{|c|c|c|c|c|c|}
\hline \multirow{2}{*}{$\begin{array}{c}\text { Elements of } \\
\text { Communication Ability }\end{array}$} & \multicolumn{3}{|c|}{ Level } & \multirow[b]{2}{*}{ Mean } & \multirow[b]{2}{*}{ Category } \\
\hline & $\begin{array}{c}\text { Low } \\
(1.00-2.33)\end{array}$ & $\begin{array}{c}\text { Fair } \\
(2.34-3.66)\end{array}$ & $\begin{array}{c}\text { High } \\
(3.67-5.0)\end{array}$ & & \\
\hline Communicative & $16(26.7 \%)$ & $24(40.0 \%)$ & $20(33,3)$ & 3.51 & Fair \\
\hline Give comments & $9(15.0 \%)$ & $32(53.3 \%)$ & $19(31.7 \%)$ & 3.57 & Fair \\
\hline Expression of opinion & $12(20.0 \%)$ & $27(45.0 \%)$ & $21(35.0 \%)$ & 3.11 & Fair \\
\hline \multicolumn{4}{|c|}{ Average } & 3.33 & Fair \\
\hline
\end{tabular}


From Table 2 above showed that the category of communication ability elements to the eleventh-grade student of SMK Negeri 2 Padang totally in the level of fair with a score of 35.1. For the detail to each sub variable of communication ability elements are in the first sub variable of communicative was 3.51 . It consisted of in the high category as much as 20 people or $(33.3 \%)$, in the fair category 24 people or $(40.0 \%)$ and the low category 16 people or $(26.7 \%)$. Second, the sub variable of sharing ideas was 3.57 in the level of fairness.

It consisted of in the high category as much as 22 people or $(36.7 \%)$, in the fair category 25 people or $(41.7 \%)$ and the low category 13 people or $(21.7 \%)$. For third sub variable of giving comments was 3.57 at the fair level which consisted of in the high category as much as 19 people or $(31.7 \%)$, in the fair category 32 people or $(53.3 \%)$ and the low category 9 people or $(15.0 \%)$ Finally, expression of opinion was 3.11 at the fair level which consisted of high category as much as 21 people or $(35.0 \%)$, in the fair category 27 people or $(45.0 \%)$ and the low category 12 people or $(20.0 \%)$. For the variable of self-control ability can be explained referred to an analysis result as follows (Table 3 ).

From Table 3 above showed that the category of Self Control elements to eleventh-grade students of SMK 2 Padang totally at the fair level with a score of 0.01 . For the detail, to each, the sub-variables are: for enjoyable was in the low level of 2.26. It consisted of in the high category as much as 11 people or $(18.3 \%)$, in the fair category 19 people or $(31.7 \%)$ and the low category 30 people or $(50.0 \%)$. Second, the sub variable of anxiety was 3.98 in the level of fairness. It consisted of in the high category as much as 7 people or $(11.7 \%)$, in the fair category 45 people or $(75.0 \%)$ and the low category 8 people or $(13.3 \%)$.

For third sub variable of emotional stability was 2.92 at the fair level which consisted of in the high category as much as 5 people or $(8.3 \%)$, in the fair category 44 people or $(73.3 \%)$ and in the low category 11 people or $(18.3 \%)$. Finally, emotional intelligence ability was 2.88 at the fair level which consisted of high category as much as 2 people or $(3.3 \%)$, in the fair category 39 people or $(65.0 \%)$ and the low category 19 people or (31.7). The influence of social engagement towards students' speaking performance can be explained by using multiple linear regression tests that can be seen in the Table 4

From the Table 4 above can be known the formulation of multiple linear regressions can be obtained as follows: $\mathrm{Y}=79,933+0,054 \mathrm{X}_{1}+0,001 \mathrm{X}_{2}-0,062 \mathrm{X}_{3}$. From the formulation, exactly we can be predictable the relationship between Independent variable with dependent variable with the explanation are 1) Each increasing the value $\mathrm{X}_{1}$ (socialization ability) at one point, then the value of $\mathrm{Y}$ (speaking performance) will be increasing by 0,054 , 2) Each increasing the value $X_{2}$ (communication ability) at one point, then the value of $\mathrm{Y}$ (speaking performance) will be increasing too with 0,001 and 3) Each increasing the value $\mathrm{X}_{3}$ (self-control) by one point, then the Y-value will drop 0,062 .

Partially three sub variables of social engagement just obtained only two positive influence on student speaking performance namely socialization ability and communication ability when teacher apply a flipped classroom mode for teaching speaking in EFL classroom. However, the first sub other variables of self-control do not affect on the students' speaking performance of English in the classroom.

Table 3

Self-Control of English Language Learners in Flipped Classroom Mode

\begin{tabular}{|c|c|c|c|c|c|}
\hline & \multicolumn{2}{|c|}{ Level } & & \multirow[b]{2}{*}{ Mean } & \multirow[b]{2}{*}{ Category } \\
\hline Elements of Self Control & $\begin{array}{c}\text { Low } \\
(1.00-2.33)\end{array}$ & $\begin{array}{c}\text { Fair } \\
(2.34-3.66)\end{array}$ & $\begin{array}{c}\text { High } \\
(3.67-5.0)\end{array}$ & & \\
\hline Satisfaction & $30(50.0 \%)$ & $19(31.7 \%)$ & $11(18,3)$ & 2.26 & Low \\
\hline Emotional stability & $11(18.3 \%)$ & $44(73.3 \%)$ & $5(8.3 \%)$ & 2.92 & Fair \\
\hline Emotional Intelligence & $19(31.7 \%)$ & $39(65.0 \%)$ & $2(3.3 \%)$ & 2.88 & Fair \\
\hline \multicolumn{4}{|c|}{ Average } & 3.01 & Fair \\
\hline
\end{tabular}

Table 4

Partially Influence of Students' Social Engagement on Their Speaking Performance in Flipped Classroom Model

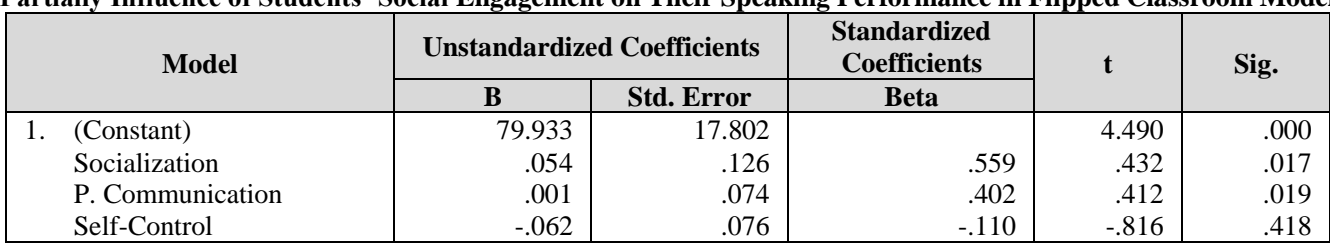

Table 5

Simultaneously Influence of Students' Social Engagement on Their Speaking Performance in Flipped Classroom Model

\begin{tabular}{|ll|r|r|r|r|r|}
\hline & Model & \multicolumn{1}{|c|}{ ANOVA } & \multicolumn{1}{c|}{$\begin{array}{c}\text { Mean } \\
\text { Square }\end{array}$} & \multicolumn{1}{c|}{ F } & Sig. \\
\hline 1 & Regression & 33.608 & 3 & 11.203 & .648 & $.041 \mathrm{a}$ \\
& Residual & 1801.642 & 56 & 32.172 & & \\
& Total & 1835.250 & 59 & & & \\
\hline
\end{tabular}

a. Predictors: (Constant), Socialization, P. Communication, Self-Control

b. Dependent Variable: Speaking Performance 
From Table 5 above can be seen that analysis of the students' social engagement have strong relationship with students English speaking performance when the teacher used flipped classroom model. It gives simultaneously affect to other students' speaking abilities with the value of $\mathrm{F}$ is 0684 , simultaneously, it means that social engagement variable has been giving to contributed $68.4 \%$ on the improvement of student speaking performance at SMK 2 Padang, while the remaining $31.6 \%$ suspected as other variables impact not included in this study.

\section{DISCUSSION}

From the finding and study analysis to three sub variables of social engagement, they are socialization ability, communication ability and self-control which in total consists of 12 themes observed. In this section presented and discussed the twelve themes as the findings of this study. As for the twelve themes are: cooperative, friendly, tolerable, adaptive, communicative, sharing ideas, give comments, expression of opinion, enjoable, anxiety, emotional stability and emotional Intelligence. Based on the findings of result analysis were known that students' socialization ability elements to eleventh grade students of SMK Negeri 2 totally of them in the high level with a score of 37.0 it means that the students' socialization ability in SMK Negeri 2 has been good enough.

Socialization ability in the four focus of cooperative, friendly, tolerable, adaptive, communicative showed that almost of all students are willing to work together and have good commitment to accomplished the work together in the group, want to invest their time to study together and effort to build their friendly relationship in working with their peer to solve the problem together in the group class. Being tolerable with different idea and being adaptive each other in the study group by using flipped classroom model. In fact, flipped classroom model can be give positive impact to improve the students' socialization ability well. Better the student socialization ability of EFL class will be better their speaking performance in the discussion and communication in the class.

The ability of students' social engagement aims to build their social skills in order being more cooperative, friendly, adaptive and respective the opinions of others both useful for supporting the cooperative learning process in the study groups of students both inside and outside of the class by using flipped classroom model. A similarity of key in the perspective of social construction is that the learning is a socially constructed learning through students' interaction, involvement and participation actively, and a generic term to social learning interaction [9].

In this view, learning is the result of a continuous transaction between students with individuals and their environment [10]. It means that the study is based on involvement, activity and participation of students in their interactions with their peers and teachers based on context and content. The role of social action between the development of students' cognition is the premise of social construction has been built by [11] known as the theory of social culture.

Zone of proximal development is the key learning concepts that can be defined as' the distance between the actual developmental level to solve the problems together according to the level of potential development of society in this case the community of EFL classroom under the guidance of a teacher or in collaboration with colleagues in study groups together. (Vygotsky, 1978:86) stated that this mechanism ultimately affects students' self-regulation. Through interaction with peers that are more capable, individuals can learn to regulate itself through the actions made by others, and integralize to himself action.

The ability of socialization development to the students is very important in determining their success in the classroom, especially for EFL students to train their speaking abilities during the discussion and argued in finding a solution to the given case. Abeysekera \& Dawson, (2015); O'Flaherty \& Phillips, (2015), Stated that the main component of the flipped classroom is to involve students in social learning and active, usually through the preparatory work (from class activities) with the collaboration of the next group (to class activity). Based on this it can be concluded that flipped classroom can work well if the social skills of students can be built well, it can boost students' social engagement to participate in the teaching learning process both inside and outside of the classroom.

To build the students' social skills through flipped classroom model is to familiarize the students learning the subject into the groups with their peers. Learning groups are very important in the flipped classroom. The findings of the flipped classroom learning group show that students' participation in their study groups can support their teaching learning process and encourage them to be more positive involvement in the discussion actively to all session of discussions and question and answer interactive either online (using social media WhatApp) as well as off line in the class. This method allows each student to ask questions, discuss and collaborate with peers in their group. By using flipped classroom, there are more possibilities for study groups, given that a classroom session is held with a lot of the time allowed for discussion in the group.

With flipped classroom model of allowing interstudents can interact actively raised many questions in the group. If the exercise is difficult, then each member will help each other to explain their understanding of the theory and the problems studied. Through the flipped classroom, teachers can provide opportunities for students to play their other roles in learning are to giving the contribution to the group. Further Vygotsky, (1978) explains that the success of social a strong engagement inside of students can make a positive contribution to his or her cooperative attitude development in the form of social interaction with their learning partners

Meanwhile the variable of communication ability, there are four themes are communicative, sharing idea, give comments, expression of opinion ability showed that not of all students have good communicative style are willing to sharing together about idea and opinion to the problem offered. Some of them did not give comment in 
the group study and lack of their expression of opinion ability in doing the thinking aloud to find out the solution of the problem given. In fact, the communication tool is a good media for EFL Learner to practice their English speaking well in the group discussion both inside the class and outside. Students with have good communication ability will be easily to practice their English as foreign language in the class when studying English speaking and it also give added value to support the student being diligent to practice their oral English performance with peer both in the class and out of the class.

Active engagement in the communication plays an important role in supporting the teaching and learning process, especially in English language learning in the field of speaking performance. By this way student can be more active in speaking English to each session of discussion, whether in the study group or individual. The implementation of flipped classroom at least enables to build the student communication abilities well trough their English-speaking practice in each learning discussion and interactive question and answer session in the classroom. Students 'ability to establish a good communication referred to as a key factor to helps his or her English speaking ability [13].

Many researchers believe that developing the communication skills of students in the classroom is an important role that teachers should be done, regardless of the meaning of the complex and multi-faceted [14]. The active involvement of student in the communication in the classroom can build various cognitive levels that ultimately affect to their learning outcome, in this study strengthening the students' communicative abilities showed a positive effect on their speaking performance. Other researchers claim the involvement of students is not only multi-faceted, but also dynamic, fluctuating, depending on the context and interactive to be built by teacher in class [15] Three key dimensions of cognitive behavior engagement and affective behavior as described by [14], is widely recognized that these two variables have a very strong relationship. In theory of social engagement [13].

Extending the view this term by calling the social engagement within the larger conceptual framework by considering various socio-cultural context in which structural factors and psychosocial effect on students' social engagement. In turn, the involvement of students in each social engagement by using the flipped classroom learning model provide a good academic consequences and social engagement for the development of the learner quality (such as improving the academic performance of students) and the strengthening of self-learning motivation (impetus to lifelong learning).

In short, the social involvement of students in terms of building the communication abilities among peers and with the teacher needs to be seen as a psycho-social process, where this process is influenced by institutional factors and personality factors. In addition, through the development of socio-cultural context of students are expected to actively encouraged in any learning activity that have been established together in the implementation of flipped classroom model. To make sure that all can be integrated well in a single unit of learning process to improve students' learning behavioral and psychological.

Data supporting this study, also supported by empirical findings are closely related to socio-cultural framework of the students involvement in foreign language learning class like as a means of students speaking practice by [13] and the core dimensions affect the cognitive and behavior of students as discussed by [14]. This dimension is recognized by [13]. Cognition refers to learning in students themselves through self-regulation of learning which have been built through social reinforcement. Dimensions of the students' social behavior associated with time and effort of students practice, interactive, and participative in each session of learning in the classroom both inside and outside of the classroom.

Finally, in the line of students 'self-control of emotional consisted of four themes. They are satisfaction, anxiety, emotional stability and emotional intelligence. The four of them mentioned above is important to support students' strengthening social ability in the new situation with of losing their temperament, and self-control emotionally through building a cooperative learning in the class. By this way, all students have the same chance to get the assistant from his or her friends in their study group. The student who above to build a good emotional stability in interactive communication, it will push them become better in question answer interactive in the flipped classroom class by executing a good manner of English Teaching to the EFL Learner to improve students' English-speaking performances.

A good developing of self-control emotionally can affect the readiness of students in learning, especially in teaching English speaking to reduce students' anxiety when they want to be actively involved in the discussions and interactive question and answer session. Affective factors such as satisfaction, self-control and anxiety associated with a learning experience and an important dimension of student engagement [13]. Some of the students in this study reflects their emotional satisfaction to relationship with their environment in getting success their learning.

The more emotionally stable person, the lower their anxiety levels and will improve their speaking performance. In contrast when emotional stability is lower, tends to increase the anxiety which caused the students become more afraid to be active in the discussion session of classroom learning. This condition is clearly hinder the progress of student learning and decreases the students speaking performance in studying English as foreign language teaching. It was caused by the instability of the emotional and students' anxieties are strongly associated with students' speaking performance is lower.

Kahu, (2013) referring to Smith, R., (2007) stated that there is a strong relationship between students' emotional stability and teacher attitude in teaching. The non pleasant classroom situation that has been made by teacher can emerge the stress situation of the class so it can affect student learning performances. For example, teacher gives a complex task, teacher does not tolerate with any mistake or teachers require students answered correctly, if do not be penalized by declining his or her 
mark and so on. Obviously, the way like this have greatly affect to students' self-control, both from the point of satisfaction, anxiety, emotional stability and emotional Intelligence, which in turn give negatively impact on students learning performance.

Kahu, stated that importance of students' selfcontrol on the most favorable conditions during the learning process can be carried out in the classroom by using the model of Flipped classroom so that students involvement becomes better that can be seen from there are being more active and creative in involving their lesson in the classroom to follow all English language learning session [13], [16].

Vygotsky, shows the importance of dialogue in the relationship between teachers and students are one of effort to build a good atmosphere of satisfaction learning class, far from anxiety and intimidation. In the implementation of Flipped classroom model, teachers should be able building the satisfaction condition in the learning environment for all students in the class, by this way can be expected to increase the students' eager to be more active and creative in the English lesson and reduce their anxiety, which in turn give a positively impact to strengthening students' emotional stability and intelligence [11].

Building a good social engagement for students via flipped classroom model can be realized by utilizing some online interactive media, in addition face to face media in the classroom. The online interactive media that can be used to improve students social engagement being more active and interactive in the class are to utilize the audiovisual media to learn a new content in the study group, use the media Google classroom as a learning space together outside the classroom and take advantage of online WhatsApp media to other types to support the group learning out of the class.

In general, students will be enthusiastic to learn by using video supported by online interaction media such as by using Google Classroom or WhatsApp online media in completing the assignment of teachers before the interactive learning in the classroom begin. Almost all of the students expressed great satisfaction with the use of audiovisual and interactive online media like Google Classroom and WhatsApp. Building this interactive can be awakening students' social engagement and strengthening their self-control is closely related to improving their learning outcomes.

\section{CONCLUSION}

From the finding and the explanation of research result mentioned above can be concluded that student's socialization ability was in the high category of 3.70 , for communication ability and self-control ability were in the fair ability with each score 3.3 and 3.01. The Relationship between social engagement and student speaking performance for English Foreign Language learner class simultaneously give positive effect, however in partially the relationship of social engagement on student speaking performance in the EFL class just two sub variable have positive relationship those are socialization ability and communication ability while for the students' self-control on the their speaking performance in the class of EFL have negative relationship.

\section{REFERENCES}

[1] R. Talbert, "Inverting the Linear Algebra Classroom," Primus, vol. 24, no. 5, pp. 361-374, 2014.

[2] S. . Wrigh, "Linear algebra and the experiences of a "flipper," Primus, pp. 627-640, 2015.

[3] N. Johnson, L., Adams Becker, S., Cummins, M., Freeman, A., Ifenthaler, D. and Vardaxis, "Technology Outlook for Australian Tertiary Education," An NMC Horiz. Proj. Reg. Anal., 2013.

[4] L. Abeysekera and P. Dawson, "Motivation and cognitive load in the flipped classroom: definition, rationale and a call for research," High. Educ. Res. Dev., vol. 34, no. 1, pp. 1-14, 2015.

[5] J. Lowell, B. Utah, M. Verleger, and D. Beach, "The Flipped Classroom: A Survey of the Research The Flipped Classrom: A Survey of the Research," Proccedings Annu. Conf. Am. Soc. Eng. Educ., p. 6219, 2013.

[6] J. Mehring, "Present Research on the Flipped Classroom and Potential Tools for the EFL Classroom," Comput. Sch., vol. 33, no. 1, pp. 1-10, 2016.

[7] B. Tucker, "The flipped classroom: Online instruction at home frees class time for learning.," Educ. Next, vol. 12, pp. 82-83, 2012.

[8] J. Creswell W, Research Design, Qualitative, Quantitative and Mixed Methods Approaches, 4th ed. SAGE Publication, Inc, 2014.

[9] J.-A. Baird, T. N. Hopfenbeck, P. Newton, G. Stobart, and A. T. Steen-Utheim, "State of the Field Review Assessment and Learning," no. 13, p. 174, 2014.

[10] A. Sfard, "On Two Metaphors for Learning and the Dangers of Choosing Just One," Educ. Res., vol. 27, no. 2, pp. 4-13, 1998.

[11] L. S. Vygotsky, Mind in Society: The Development of Higher Psychological Processes, London, UK. 1ONDO: Harvard University Press, 1978.

[12] J. O'Flaherty and C. Phillips, "The use of flipped classrooms in higher education: A scoping review," Internet High. Educ., vol. 25, no. February 2015, pp. 8595, 2015.

[13] E. R. Kahu, "Framing student engagement in higher education," Stud. High. Educ., vol. 38, no. 5, pp. 758-773, 2013.

[14] J. A. Fredricks, P. C. Blumenfeld, and A. H. Paris, "School Engagement: Potential of the Concept, State of the Evidence," Rev. Educ. Res., vol. 74, no. 1, pp. 59-109, 2004.

[15] G. A. Goldin, Y. M. Epstein, R. Y. Schorr, and L. B. Warner, "Beliefs and engagement structures: Behind the affective dimension of mathematical learning," ZDM - Int. J. Math. Educ., vol. 43, no. 4, pp. 547-560, 2011.

[16] Smith, R., "An Overview of Research on Student Support: Helping Students to Achieve or Achieving Institutional Targets? Nurture or de-Nature?"," Teach. High. Educ., vol. 12, no. 5, pp. 683-695, 2007. 